\title{
HERC2 Gene
}

National Cancer Institute

\section{Source}

National Cancer Institute. HERC2 Gene. NCI Thesaurus. Code C117247.

This gene is involved in both protein ubiquitination and DNA damage repair. 